\title{
Location decisions of heterogeneous European firms
}

\author{
Josep Martí* \\ Department of Economics and Institute of International Economics, Universitat Jaume I, Castellón, Spain
}

Received: 29 November 2019

Revised: 14 February 2020

Accepted: 26 February 2020

\begin{abstract}
We analyze empirically how firms' characteristics affect the foreign affiliates location decisions of heterogeneous firms in different markets. Using a European firm-level data and estimating the marginal effects for the multinomial logit model, the results corroborate the relevance of firms' characteristics in their investment decisions, particularly the productivity level.
\end{abstract}

Keywords: multinational firms; firm heterogeneity; location decision; European firms JEL Classification Codes: F14, F21, F23

\section{Introduction}

A scarce literature on FDI in recent years has emphasized the relevance of firms' heterogeneity on the location decisions of the foreign affiliates by the multinational firms (Aw and Lee, 2008; Yeaple, 2009; Chen and Moore, 2010; Ascani et al., 2016) ${ }^{1}$. Above studies pointed out the importance of firms' heterogeneity in their foreign investment activity, paying special attention to the productivity level. The purpose of this study is to provide empirical evidence about this topic. Particularly, as in Aw and Lee (2008), this study focuses on the role played by the firm characteristics on the foreign affiliate location decisions for the case of European firms. It differs from earlier work on the matter in two important regards. Firstly, we study the case for firms from six developed European economies (Germany, France, Italy, Spain, United Kingdom and Austria) in the manufacturing sector, which can locate a foreign affiliate to different Northern and Southern economies ${ }^{2}$. Secondly, we analyze the effects of the firms' characteristics on the location decisions of multinational firms by estimating the average marginal effects (AMEs) for the multinomial logit (MNL) model. The AMEs results provide

\footnotetext{
*E-mail: arnauj@uji.es.
}

Citation: Martí, J. (2020) Location decisions of heterogeneous European firms, Economics and Business Letters, 9(3), 265-269.

DOI: 10.17811/ebl.9.3.2020.265-269

\footnotetext{
${ }^{1}$ While Aw and Lee (2008) examines what the extent firms' characteristics reflect the underlying patters of firms' location decisions, Yeaple (2009), Chen and Moore (2010) or Ascani et al. (2016), pay more attention on how host country's characteristics affect the location structure of multinationals activity.

${ }^{2}$ Aw and Lee (2008) analyze the case of firms from a middle-income country (Taiwan) that invest in a single developed or developing economies (USA and China), respectively.
} 
us a better interpretation of the effects of the firms' characteristics on the probability to invest in one of the host locations considered in this study.

\section{Data}

This study is based on firm-level data for case of European firms in manufacturing sector (EFIGE). This database combines different measures of firms' international activities with quantitative and qualitative information of headquarters in year $2008 .{ }^{3}$ Particularly, our data consists in 571 firms investing in the following markets: EU15, Central and Eastern European countries $(\mathrm{C} \& \mathrm{E})$, China and India $(\mathrm{C} \& \mathrm{I})$, USA and Canada (U\&C), and Central and South American countries $(\mathrm{C} \& S)$.

Table 1. Distribution of production by European affiliates, by destinations.

\begin{tabular}{|c|c|c|c|c|c|c|c|c|}
\hline & $\begin{array}{r}\text { Firms } \\
\text { (number) }\end{array}$ & $\begin{array}{r}\text { Host } \\
\text { market }\end{array}$ & $\begin{array}{r}\text { Imported } \\
\text { to home } \\
\text { country } \\
\text { for use in } \\
\text { production }\end{array}$ & $\begin{array}{r}\text { Imported } \\
\text { to home } \\
\text { country } \\
\text { to be di- } \\
\text { rectly } \\
\text { sold }\end{array}$ & $\begin{array}{r}\text { Imported } \\
\text { to home } \\
\text { country } \\
\text { to be re- } \\
\text { exported } \\
\text { to 3rd } \\
\text { markets }\end{array}$ & $\begin{array}{r}\text { Exported } \\
\text { to } 3 r d \\
\text { markets } \\
\text { where } \\
\text { the firms } \\
\text { does not } \\
\text { produce }\end{array}$ & $\begin{array}{r}\text { Exported to } \\
\text { 3rd markets } \\
\text { where other } \\
\text { production } \\
\text { facilities are } \\
\text { located }\end{array}$ & $\begin{array}{r}\text { Percentage } \\
\text { of firms in- } \\
\text { volved in a } \\
\text { single dis- } \\
\text { tribution } \\
\text { strategy }\end{array}$ \\
\hline EU15 & 272 & 60.7 & 42.3 & 44.9 & 30.9 & 43.8 & 25.0 & 32.7 \\
\hline C\&E & 94 & 38.3 & 45.7 & 56.4 & 44.7 & 50.0 & 11.7 & 27.7 \\
\hline C\&I & 99 & 40.0 & 60.0 & 62.1 & 62.1 & 40.0 & 10.5 & 22.1 \\
\hline $\mathrm{U} \& \mathrm{C}$ & 60 & 76.3 & 32.2 & 23.7 & 30.5 & 40.7 & 11.9 & 49.2 \\
\hline C\&S & 16 & 78.6 & 21.4 & 21.4 & 7.1 & 35.7 & 7.1 & 64.3 \\
\hline
\end{tabular}

Notes: values are expressed as a percentage of the total number of foreign affiliates in each destination.

Table 1 summarizes the destination of production by foreign affiliates of European firms in different host markets, ${ }^{4}$ which are broken down into six categories. One streaking feature that we can clearly appreciate is that the vast majority of European firms invest in other European economies (EU15 and C\&E), while C\&I is the most important investment destination outside EU.

Another important fact is that European firms investing in one of the five markets considered, do not only sell to the host market, but also import back home or export to third markets. This corroborates the relevance of export platform (Ekholm et al., 2007), as well as the role played by the market potential in the investment location choices (Baltagi et al., 2007; Blonigen et al., 2007). However, it seems that the vast majority of firms investing in U\&C and C\&S markets tend to sell their production in the host markets, pointing out the Horizontal motivation of these investments.

Table 2. Descriptive statistics of European firms by investment location (means).

\begin{tabular}{lrrrrr}
\hline \hline & $\boldsymbol{E} \boldsymbol{U 1 5}$ & $\boldsymbol{C} \boldsymbol{E}$ & $\boldsymbol{C \& \boldsymbol { I }}$ & $\boldsymbol{U} \boldsymbol{C}$ & $\boldsymbol{C} \boldsymbol{E} \boldsymbol{~}$ \\
\hline TFP & 0.22 & 0.048 & 0.07 & 0.37 & 0.42 \\
Size & 226.06 & 195.22 & 155.63 & 225.35 & 201.12 \\
K/L & 5.10 & 4.63 & 5.08 & 5.08 & 5.00 \\
HK & 141.37 & 39.12 & 52.24 & 80.00 & 25.14 \\
R\&D & 29.57 & 12.78 & 8.74 & 20.38 & 11.00 \\
\hline \hline
\end{tabular}

Notes: The TFP is measured as the Solow residual of a Cobb-Douglas production function estimated following the semi-parametric algorithm proposed by Levinsohn and Petrin (2003), at the firm level, 2002-2008 (provided by EFIGE database). The Size is the total number of employees, K/L represents the Capital intensity as natural logarithm of capital labour ratio, HK is the number of white collars and R\&D is the number of employees that have been involved in R\&D activities.

\footnotetext{
${ }^{3}$ Although the vast majority of variables included in this database are related to the year 2008, some variables, such as TFP, are calculated using data from previous years.

${ }^{4}$ Note that although the vast majority of European firms only invest in one of these markets, there are also some firms that invest in multiple destinations. Therefore, we define the main investment location for these firms based upon the host market that produce the largest share of their production $(\geq 50 \%)$.
} 
Table 2 provides the descriptive statistics of European firms' characteristics related with the firms' efficiency, investing in different locations. ${ }^{5}$ The output indicates that in average terms, European firms investing in C\&S are the most productive, followed by those firms investing in U\&C and EU15, while the least productive firms invest in C\&I and C\&E markets, respectively. Moreover, we also find that the largest firms invest in developed markets (EU15 and U\&C), while the most K/L, HK and R\&D intensives invest in EU15. These results seem to corroborate the relevance of the role played by the firm heterogeneity in order to invest in different markets, which is the main aim in this study.

\section{Empirical methodology}

We use the MNL model to analyze how firms' characteristics drive the European firms investment decisions. ${ }^{6}$ According to McFadden (1974), the MNL assumes that each investor that faces a finite set of mutually exclusive locations, $N$, selects the location $i$ that yields the highest profit $\pi_{i}=\alpha_{i}+\beta_{i} x+\varepsilon$, where $\alpha_{i}$ is location-specific parameters, $x$ captures the set of observed firm characteristics related with the firms' efficiency which are heterogeneous among firms, and $\varepsilon$ is the unobservable component.

Given that $\varepsilon$ is an unknown parameter, the firm location decision is predicted in terms of probability and thus, we should impose a probability density function on $\varepsilon$. In particular, if we consider that the error term is independently and identically distributed (iid) with type I extreme value distribution, ${ }^{7}$ the probability of a firm invest in the foreign market $i$ is given by,

$$
\operatorname{Pr}(i)=\frac{\exp \left(\alpha_{i}+\beta_{i} x\right)}{\sum_{j=1}^{5} \exp \left(\alpha_{j}+\beta_{j} x\right)}
$$

where $\operatorname{Pr}(i)=\operatorname{Pr}\left(\pi_{i}>\pi_{j}\right)$ and $i=1,2,3,4,5$ represents the foreign markets of EU15, C\&E, C\&I, U\&C and C\&S, respectively. Since $\sum_{j} \operatorname{Pr}_{j}=1$, the $N$ sets of parameters $\alpha$ and $\beta$ are not unique. Therefore, in order to identify the parameters $\alpha_{i}$ and $\beta_{i}$, we need to fix the coefficients for one alternative, in this case location 1 (EU15), to zero (that is, $\alpha_{1}=0$ and $\beta_{1}=0$ ). ${ }^{8}$ In fitting such a model, the estimated MNL model becomes,

$$
\operatorname{Pr}(i)=\frac{\exp \left[\alpha_{i}^{\prime}+\beta_{i}^{\prime} x\right]}{1+\sum_{j=1}^{5} \exp \left[\alpha_{j}^{\prime}+\beta_{j}^{\prime} x\right]}
$$

where, according to Eq. 2, the constant term $\alpha_{i}^{\prime}=\left(\alpha_{i}-\alpha_{1}\right)$ depicts the country-wide characteristics that are invariant across firms (Aw and Lee, 2008), while the coefficient $\beta_{i}^{\prime}=$ $\left(\beta_{i}-\beta_{1}\right)$ represents the effect of the $x$ covariate factors (firm characteristics) on the probability of investing in alternatives 2, 3, 4 or 5 rather than the alternative to invest in 1 (EU15).

While predicted probabilities provide us information about the direction and magnitude of the relationship, it may be difficult to precisely determine whether a relationship can really be established. Thus, in order to obtain a better interpretation of our results about the direction and magnitude of the relation between an independent and dependent variable in the MNL, we also

\footnotetext{
${ }^{5}$ While the previous studies (s.e. Aw and Lee, 2008; Yeaple, 2009) emphasizes the firms' productivity level as the discriminatory determinant on the investment location decisions, we also analyze other firms characteristics that have been also identified as relevant related to the firms efficiency by the literature, such as size, capital labour ratio, human capital and $R \& D$.

${ }^{6}$ This methodology provides an adequate framework in which to analyze firm location decisions when a set of choices are considered and the choice among alternatives is modeled as a function of the firms' characteristics.

${ }^{7}$ The iid assumption on the unobservable term $\varepsilon$ imposes the property of independence of irrelevant alternatives (IIA).

${ }^{8}$ To identify parameters in this methodology, it is necessary to establish one of the possible destinations as the base location and to set its parameters to zero. Thus, the remaining coefficients would measure the relative change with respect to this base group or investment location.
} 
estimate the AMEs. ${ }^{9}$ The AMEs are defined as the slope of the prediction function at a given value of the explanatory variable, and therefore, inform us about the change in predicted probabilities due to a change in a particular predictor.

\section{Results}

Since our interest lies in explaining the firm-level determinants and their effects on firm's investment location decisions, we will mostly base the discussion of the results on the estimated AMEs presented in Table $3 .{ }^{10}$ The AMEs are a more direct interpretation of the effects of the explanatory variables on the probability of choosing a particular location. In particular, the AMEs in Table 3 show that differences in productivity level (proxied by TFP) are the main determinant in the investment location decisions by European firms. Concretely, we obtain that an increase in the TFP, encourage European firms to invest to EU15, U\&C (developed economies) and $\mathrm{C} \& \mathrm{~S}$, in this order. This result is probably due to a horizontal motivation of the investments in these locations, as can be appreciated in Table 1, while discourage investments in the less developed economies $(\mathrm{C} \& \mathrm{E}$ and $\mathrm{C} \& \mathrm{I})$. Which suggest that the most productive firms are more likely to invest to most developed economies rather than developing countries. This agrees not only with the empirical results obtained by Aw and Lee (2008), but also with previous theoretical models (Grossman et al., 2006; Aw and Lee, 2008). According to these theoretical models, at a given level of the host country's characteristics, firms investing in the developed economies are predicted to have higher productivity level than firms investing in developing countries. Furthermore, we also obtain that while increasing size and HK encourage investments in EU15, an increasing in $\mathrm{K} / \mathrm{L}$ incentives firms to invest in $\mathrm{C} \& \mathrm{E}$ (both EU region). However, we do not find any clear evidence about the effects of the other firms' characteristics on the probability to invest in the rest of locations (non-EU regions).

Table 3. Average Marginal Effects (AMEs) for MNL.

\begin{tabular}{lrrrrr}
\hline $\begin{array}{l}\text { Independent } \\
\text { Variables }\end{array}$ & $\boldsymbol{E} \boldsymbol{U 1 5}$ & $\boldsymbol{C} \& \boldsymbol{E}$ & $\boldsymbol{C} \& \boldsymbol{I}$ & $\boldsymbol{U} \boldsymbol{C}$ & $\boldsymbol{C} \& \boldsymbol{S}$ \\
\hline TFP & $0.10(0.05)^{\mathrm{b}}$ & $-0.08(0.03)^{\mathrm{b}}$ & $-0.10(0.04)^{\mathrm{b}}$ & $0.06(0.03)^{\mathrm{c}}$ & $0.03(0.01)^{\mathrm{b}}$ \\
Size & $0.03(0.01)^{\mathrm{b}}$ & $-0.01(0.01)$ & $-0.03(0.01)^{\mathrm{b}}$ & $0.01(0.01)$ & $0.01(0.01)$ \\
$\mathrm{K} / \mathrm{L}$ & $0.04(0.03)$ & $0.06(0.01)^{\mathrm{a}}$ & $0.01(0.02)$ & $0.01(0.02)$ & $-0.01(0.01)$ \\
$\mathrm{HK}$ & $0.04(0.01)^{\mathrm{a}}$ & $-0.03(0.01)^{\mathrm{b}}$ & $-0.01(0.01)$ & $-0.01(0.01)$ & $0.01(0.01)$ \\
R\&D & $0.01(0.02)$ & $-0.01(0.01)$ & $-0.01(0.02)$ & $0.01(0.01)$ & $0.01(0.01)$ \\
\hline \hline
\end{tabular}

Note: Standard errors are in parentheses where a, b and c denote significance at the $1 \%, 5 \%$ and $10 \%$ levels, respectively. Additionally, Home Country and Industry fixed effects are also included on MNL estimations.

\section{Conclusions}

This study analyzes empirically the investment location decisions of heterogeneous European firms. The results after estimate the AMEs for MNL corroborate the relevance of firms' heterogeneity in these decisions, and particularly, the importance of the productivity level. Moreover, we conclude that while increasing the productivity level encourage firms to invest in the most developed economies, discourage investments in the less developed. This has important policy implications, particularly, given that in recent years, the weight of FDI inflows have dropped significantly in the most developed economies, while have increased in less developed economies (UNCTAD, 2008). These two opposite situations would call for very different policies in order to not only attract more FDI, but also the most productive firms.

\footnotetext{
${ }^{9}$ See, Bowen and Wiersema (2004).

${ }^{10}$ The MNL assumes that the ratio of the probabilities of any pair of alternatives is independent from the remaining choices (IIA). The Hausman test statistics obtained in this study for the MNL model estimations take negative values in every estimation performed, which can be interpreted as strong evidence against rejecting the null hypothesis that the IIA assumption holds (see Hausman and McFadden, 1984, footnote 4).
} 
Therefore, understanding how firm-level productivity translates into firms' location decisions remains a key priority for policymakers in both type of economies.

\section{References}

Ascani A., Crescenzi, R., and Iammarino, S. (2016) Economic institutions and the location strategies of European multinationals in their geographic neighborhood, Economic Geography, 92(4), 401-429.

Aw, B. Y., and Lee, Y. (2008) Firm heterogeneity and location choice of Taiwanese multinationals, Journal of International Economics, 75(1), 167-179.

Baltagi, B. H., Egger, P., and Pfaffermayr, M. (2007) Estimating models of complex FDI: Are there third-country effects?, Journal of Econometrics, 140(1), 260-281.

Blonigen, B. A., Davies, R. B., Waddell, G. R., and Naughton, H. T. (2007) FDI in space: Spatial autoregressive relationships in foreign direct investment, European Economic Review, 51(5), 1303-1325.

Bowen, H. P., and Wiersema, M. F. (2004) Modeling limited dependent variables: Methods and guidelines for researchers in strategic management, in Research methodology in strategy and management (Emerald Group Publishing Limited) 87-134.

Chen, M., and Moore, M. (2010) Location decision of heterogeneous multinational firms, Journal of International Economics, 80(2), 188-199.

Ekholm, K., Forslid, R., and Markusen, J. R. (2007) Export-platform foreign direct investment, Journal of the European Economic Association, 5(4), 776-795.

Grossman, G. M., Helpman, E., and Szeidl, A. (2006) Optimal integration strategies for the multinational firm, Journal of International Economics, 70(1), 216-238.

Hausman, J. A., and McFadden D. (1984) Specification Tests for the Multinomial Logit Model, Econometrica, 52(5), 1219-1240.

McFadden, D. (1974) Conditional Logit Analysis of Qualitative Choice Behaviour, in: Zarembka, P. (Ed.), Frontiers in Econometrics, Chap. 4 (Academic Press), 105-142.

UNCTAD (2018) World Investment Report 2018: Key Messages and Overview, United Nations, New York and Geneva.

Yeaple, S. R. (2009) Firm heterogeneity and the structure of US multinational activity, Journal of International Economics, 78(2), 206-215. 